Aiste Barbora Uspuriene doctor of pedagogical sciences, associate professor Julija Svipaite student Lithuanian Sports University Kaunas, Lithuania

DOI $10.21661 / \mathrm{r}-554969$

\title{
THE EFFECT OF DANCE ON GIRLS' MOTOR ABILITIES
}

Abstract: it is often forgotten that the health of the body, the ability to overcome stress and weakness depend on a person's physical activity and movement. Movement is an inexhaustible means of self-expression, self-realization and cognition of the surrounding world. Research aim - to analyze the literature and to reveal aspects of the effect of dance on girls' motor abilities.

Keywords: dance, physical fitness, balance, coordination.

Уипурене Айсте Барбора д-р пед. наук, преподаватель, лектор

Свипайте Юлия

студентка

Литовский университет спорта

г. Каунас, Литовская Республика

\section{ВЛИЯНИЕ ТАНЦЕВ НА МОТОРИКУ ДЕВОЧЕК}

Аннотация: люди часто забывают, что физическое здравие, способность справляться со стрессом и слабостью напрямую зависит от физической активности человека. Любое движение является основным способом самовыражения, самосовершенствования и познания окружающего мира. Целями данного исследования является анализ соответствующей литературы, а также попытка раскрыть аспекты влияния танцев на моторику девочек.

Ключевые слова: танец, физическая культура, баланс, координация. 


\section{Introduction}

It is often forgotten that the health of the body, the ability to overcome stress and weakness depend on a person's physical activity and movement. Movement is an inexhaustible means of self-expression, self-realization and cognition of the surrounding world. It begins with the baby's first movements, the first precarious steps, the first joy of movement, it is an inexhaustible source of happiness for the baby, as well as a rich source of adventure, self-confidence and physical and mental experience (Karim \& Qaisar, 2020). Physical activity is closely linked to the very important human mobility skills, the development of which is included in many sports programs from childhood. The human body is a whole and the activity of individual organs affects the whole body of an athlete. Therefore, the dancer's ability to dance qualitatively and for an appropriate period of time in lessons or on stage depends very much on how correctly his body is prepared for it (Park et al., 2014). The amplitude of movements of pop style dancers depends on the mobility, balance and coordination skills of certain joints. Research aim - to analyze the literature and to reveal aspects of the effect of dance on girls' motor abilities.

\section{Results and Conclusions}

Children's physical capacity is related to physical development and physical activity. As physical activity increases and its quality changes, so does physical development and physical capacity. Lack of physical activity is one of the main global health problems because it is associated with negative effects on the body: aging, weight control, lack of longevity and quality of life. The growth of children should be monitored through a larger prism, as this continuous process of movement begins at the stage of fetal development, continues into infancy, early childhood and continues into adolescence. Somatic growth in childhood and adolescence is very important because it lays the foundation for a person's future health status and is related to his or her weight status as an adult and the prevention of cardiovascular disease (Karim \& Qaisar, 2020). Children aged 11-15 undergo significant physical and mental changes in the body. The bone system is strengthening, but there is still the possibility of spinal deformity and growth retardation. Muscles develop intensively, muscle strength 
increases. Coordination continues to develop, but flexibility is greatly reduced. The nervous system quickly becomes acquainted with new sensations, so talent can emerge and thus specialization is selected. One of them may be dancing.

Dance is a unique sport and art phenomenon. Artistic expressiveness is created by body movements, elements of sports, dance and acting (Esen, 2012). Dance is defined as a creative, unique, but at the same time universal phenomenon arising from culture, which includes body movements, self-expression, feelings, stories, the body's interaction with itself and others. Dance as an art combines psychological, cognitive, emotional and sociocultural human aspects. From an artistic perspective, dance is also characterized by a sense of freedom, the aesthetic satisfaction of dance (Vukadinovic, 2012). Dancing means excitement, dancing means conquering space, the courage to overcome mobility. It's the plastic movements, gestures, and steps that are performed consistently to a particular piece of music, it's the emotional content of the exterior. Dance is a special expression of human motor behavior, it is the art of reflecting one's inner world to the outside, self-expression through movements (Cantekin, 2011). Dance, which includes sports, science and art, is a feeling expressed through a moving body, expressions of a physiological process (Esen, 2012). Dance offers many benefits and teaches us harmonious full body language (Budeanca-Babolea \& Ortanescu, 2014). Dance is emphasized as a rhythmic, musical movement based on created choreography or, it develops both artistic and physical abilities. Properly organized dance activities are focused on the expression of the inner world of the personality and affect the physical and mental functions of the body, ethical and aesthetic attitudes of the individual.

Dancing is a form of physical activity associated with health benefits that last a lifetime, even during an amateur activity. There is growing evidence of the health benefits of dance. Non-interventional comparative studies (testing currently dancing participants versus non-dancers) reported improved cardiovascular fitness, torso strength, dynamic balance, and bone mineral content in dancers compared to other agematched and non-gendered controls (Donath et al., 2014). There is growing evidence that dance and dance movements stimulate brain activity and increase neuroplasticity, and that dance experiences an aesthetic experience of movement and dance 
(Vukadinović \& Marković, 2011). Another systematic review examining the identified health benefits of dance: improved aerobic strength, lower body muscle endurance, strength, flexibility, balance, mobility, and gait. Dance training enhances the accuracy of the somatosensory system and effectively transfers visual-dominated sensorimotor balance control to the internal reference system (Park et al., 2014). Therefore, how dancers adapt to static and dynamic conditions and choose the right body position depends on strength, the responsiveness of their proprioceptive system, and advanced spatial skills (Ergen \& Ulkar, 2008).

Thanks to dance, people have the opportunity to exercise more. Support yourself emotionally, mentally, socially and physically and understand the connection between body and mind (Strassel et al., 2011). Dancing, as the most aesthetic and rhythmic mode of movement, is a technical and complex activity that involves exercises that strengthen the skeletal muscle system and improve coordination, allowing the body to move freely in space (Temel \& Temel, 2016). The feature of balance is very important for dancers. The dances are dominated by sudden movement dynamics, unexpected poses, stops and many turns, so it is necessary to ensure optimal static and dynamic balance.

Proper coordination of dancers is a prerequisite for achieving aesthetic line and form and performing movements effectively. Pelvic leveling is a common deficiency of dancers, resulting in improper technique and deteriorating performance. Dancers must be able to achieve their personal neutrality in order to avoid injuries and to easily perform the tasks assigned to them (Yin, et al., 2019).

Up to professional dance training is challenging and requires great physical and artistic abilities. Long training hours combined with frequently repetitive movement patterns during puberty and development to the professional dancer are very difficult as he is in a vulnerable position given the risk of injury. A number of sources say that musculoskeletal injuries are an important health problem for professional dancers. In terms of disease risk, moderate-intensity dancing has been reported to reduce the risk of cardiovascular mortality (Merom et al., 2018). Dance interventions have also been proposed to reduce body mass index (BMI) from high-risk to normal in adolescents. 
The positive effects of dance on cardiovascular fitness, bone health and obesity prevention continue to be supported by a systematic review of the health benefits of dance for children and young people (Burkhardt \& Brennan, 2014).

\section{References}

1. Budeanca-Babolea, O. B., Ortanescu, D. (2014). The Role And Influence Of Dance On The Coordination Abilities Of Children With Special Educational Needs. Editorial Staff, 2(24).

2. Burkhardt, J. \& Brennan, C. (2014). The effects of recreational dance interventions on the health and well-being of children and young people: a systematic review. Arts Health, 4(2):148-61.

3. Cantekin, D., 2011. Examination of movement related terms used in dance. Master thesis. Sakarya (Turkey): Sakarya University, Institute of Social Sciences.

4. Donath, L., Roth, R., Hohn, Y., Zahner, L., Faude, O. (2014). The effects of Zumba training on cardiovascular and neuromuscular function in female college students. Eur J Sport Sci, 14(6), 569-77.

5. Ergen E., Ulkar B. (2008). Proprioception and ankle injuries in soccer. Clin Sports Med, 27(1): 195-217.

6. Esen, A., 2012. The effect of dance training on joint position sensing levels. Master Thesis. İzmir (Turkey): Ege University, Health Sciences Institute.

7. Karim, A., \& Qaisar, R. (2020). Anthropometric measurements of schoolgoing-girls of the Punjab, Pakistan. BMC pediatrics, 20, 1-13.

8. Merom, D., Ding, D., Stamatakis, E. (2016). Dancing participation and cardiovascular disease mortality: a pooled analysis of 11 population-based British cohorts. Am J Prev Med, 50(6): 756-60.

9. Park, J.Y., Lee, J.C., Bae, J.J., Cheon, M.W. (2014). The effect of proprioceptive exercise on knee active articular position sense using biodex system. Transactions on Electrical and Electronic Materials, 15(3): 170-173.

10. Strassel, J.K., Cherkin, L., Steuten, K.J., Vrijhoef, H.J.M. (2011). A systematic review of the evidence for the effectiveness of dance therapy. Alternative Therapies, 17(3): 50-59. 
11. Temel, S. D. \& Temel, T. (2016). The contribution of dance education to physical-mental development, movement ability and learning processes. Fine Arts (NWSAFA), 11(4): 171-180.

12. Vukadinovic, M. (2012). An Audience's Subjective Experience of the Freedom of Artistic Expression in Different Dance Forms from the Perspective of the Cultural Psychology of Creativity. Universitas Psychologica, 12 (3), 1-38.

13. Vukadinović, M., Marković, S. (2011). Aesthetic Experience of Dance Performances. Psichologija, 45(1), 23-41.

14. Yin, A. X., Geminiani, E., Quinn, B., Owen, M., Kinney, S., McCrystal, T., \& Stracciolini, A. (2019). The evaluation of strength, flexibility, and functional performance in the adolescent ballet dancer during intensive dance training. Pm\&r, 11(7), 722-730. 